\title{
Sensorineural Hearing Loss and Wernicke Encephalopathy: A Case Report and Literature Review
}

\author{
Angie Nu Ton ${ }^{1}$, Trisha Jethwa ${ }^{1}$, Greta C Stamper ${ }^{2}$, and Ashley Yenior ${ }^{1}$ \\ ${ }^{1}$ Departments of Family Medicine, ${ }^{2}$ Audiology, Mayo Clinic, Jacksonville, FL, USA
}

$\begin{array}{ll}\text { Received } & \text { February 6, 2020 } \\ \text { Revised } & \text { April 22, 2020 } \\ \text { Accepted } & \text { April 30, 2020 }\end{array}$

Address for correspondence

Angie Nu Ton, MD

Department of Family Medicine,

Mayo Clinic, 4500 San Pablo Road,

Jacksonville, FL 32224, USA

Tel +1-904-953-6722

Fax +1-904-953-0626

E-mail ton.angie@mayo.edu
Sensorineural hearing loss (SNHL) is seldom associated with Wernicke encephalopathy (WE) or thiamine deficiency. While thiamine deficiency and repletion are often considered prior to dextrose infusions in patients with chronic alcohol abuse to prevent WE, they are often overlooked in non-alcoholic patients who are also at risk for malnutrition. In this paper we describe a case of a non-alcoholic 28-year-old female status post-sleeve gastrectomy who developed SNHL in the setting of thiamine deficiency and WE, with ongoing hearing impairment requiring hearing aids despite thiamine repletion.

J Audiol Otol 2021;25(1):55-58

KEY WORDS: Wernicke encephalopathy · Thiamine deficiency · Hearing loss.

\section{Introduction}

Wernicke encephalopathy (WE) is a syndrome that arises from thiamine (vitamin B1) deficiency and is typically characterized by nystagmus, ataxia, and confusion, with at least two of these characteristics being present [1]. Magnetic resonance imaging (MRI) is not required for the diagnosis of WE, as it has been shown to have an estimated sensitivity of $53 \%$ in revealing WE [2]. WE and thiamine deficiency are commonly known as complications of chronic alcoholism. However, non-alcoholic causes are becoming more recognized, including hyperemesis gravidarm, chemotherapy-induced hyperemesis, and bariatric surgery [3]. WE after bariatric surgery has been shown to present with atypical neurological features, outside the classic triad, including third and sixth cranial nerve palsies [4]. However, hearing loss is considered rare $[3,4]$.

In this paper we describe the case of a 28 -year-old female who developed sensorineural hearing loss (SNHL) in the setting of thiamine deficiency and acute WE after bariatric surgery, requiring hearing aids despite thiamine replacement.

This is an Open Access article distributed under the terms of the Creative Commons Attribution Non-Commercial License (https://creativecommons.org/licenses/by-nc/4.0/) which permits unrestricted non-commercial use, distribution, and reproduction in any medium, provided the original work is properly cited.

\section{Case Report}

A 28-year-old female presented to a clinic with difficulty hearing, which had been ongoing without change for one year since her hospitalization for hyperemesis status three months post-sleeve gastrectomy. She had no history of ototoxic medications, auditory or physical trauma, or ear surgery, no recurrent history of otitis media or congenital anomalies, and no family history of early-onset hearing loss. During her hospitalization one year prior to visiting the clinic, she was given intravenous (IV) $5 \%$ dextrose in half-normal saline due to her five-day history of hyperemesis and starvation ketosis. On day four of hospitalization, she developed new-onset diplopia and gait ataxia. Her exam was significant for horizontal nystagmus and ataxic gait, including difficulty with tandem walking. The remainder of her neurological exam was normal. Her hearing was preserved and she could hear speech and was able to localize a finger rustling bilaterally. Her brain MRI was normal. Laboratory workup revealed a thiamine deficiency $(59 \mathrm{nmol} / \mathrm{L}$, with the normal reference range being $70-180 \mathrm{nmol} / \mathrm{L}$ ).

Having met the diagnostic criteria, a clinical diagnosis of WE was established [1]. Treatment with IV thiamine was initiated (500 mg infused over 30 minutes three times daily for three days followed by $250 \mathrm{mg}$ once daily for an additional five days). Her nystagmus and ataxia improved the follow- 
ing day after treatment initiation. Her thiamine levels corrected after the completion of the thiamine treatment course and she was discharged in a stable condition, with a return to her baseline values after a total hospital course of five days.

Two months after hospital discharge, the patient began noticing diminished hearing in both ears. She described increased difficulty understanding speech on the telephone and when not facing the speaker. She also noted that she required an increased volume when watching television. She did not seek evaluation until nearly one year after the onset, stating she was in disbelief that she was having hearing loss given her young age. Her thiamine levels remained within normal limits one-year post-hospitalization (143 nmol/L). On otoscopic inspection, both ears had patent canals and normal, intact tympanic membranes, with easily recognizable landmarks. The tympanograms were normal bilaterally. The audiogram (Fig. 1) showed a speech reception threshold of 25 $\mathrm{dB}$ HL bilaterally. When presented at $55 \mathrm{~dB} \mathrm{HL}$, word recognition was $82 \%$ in the right ear and $87 \%$ in the left ear. The pure tone averages were $30 \mathrm{~dB} \mathrm{HL}$ (right ear) and $25 \mathrm{~dB} H \mathrm{HL}$ (left year). This is consistent with a mild and a slight sensorineural hearing loss in the right and left ear, respectively. In the left ear, distortion product otoacoustic emissions (DPOAEs) were present from 1 to $3 \mathrm{kHz}$ and were absent at $500 \mathrm{~Hz}$ and from 4 to $10 \mathrm{kHz}$. In the right ear, they were absent from 0.5 to $10 \mathrm{kHz}$.

The patient was fitted with bilateral hearing aids and subjective improvement in symptomatic hearing loss was re-

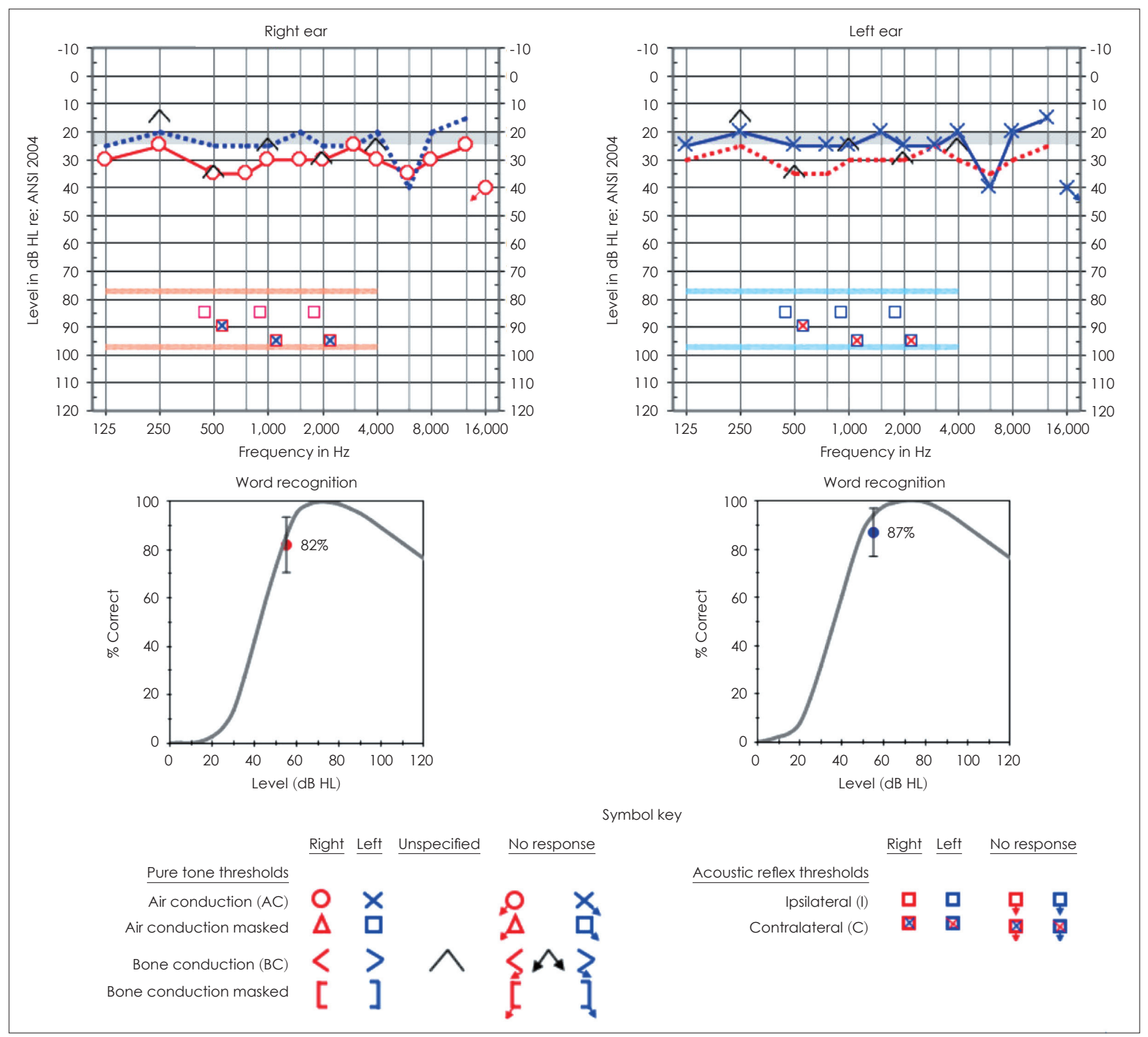

Fig. 1. Audiogram showing mild and slight sensorineural hearing loss in the right and left ear, respectively, status one year post-acute Wernicke encephalopathy and thiamine repletion. 
ported. Given her unremarkable personal and family history, genetic testing was deferred. She continued with routine vitamin supplementation and close monitoring and her thiamine levels remained within normal limits.

\section{Discussion}

Sensorineural hearing loss has been attributed to various types of vitamin deficiencies, such as vitamin D [5]. However, it is rarely associated with thiamine deficiency and it is generally not considered a syndrome of WE. Nevertheless, there is a growing number of case reports describing hearing loss associated with WE. Our literature review yielded ten case reports of SNHL occurring with WE prior to thiamine repletion (Table 1). The SNHL resolved within two weeks or less after thiamine replacement treatment in $4 / 10$ cases [3,6-8], improved but persisted within three months or less in $5 / 10$ cases [9-13], and was not reported in one case [14]. Only 4/10 cases performed an audiogram at the time of presentation, all showing moderate SNHL $[3,10,12,13]$, and a follow-up audiogram was performed after thiamine replacement in only one case. Nakamura, et al. [12] presented a moderate SNHL which improved to a mild SNHL status three months post-thiamine repletion. None of the cases reported DPOAEs. However, Prosperini, et al. [13] did report on brainstem auditory- evoked response testing that demonstrated bilateral prolonged I-III interpeak latencies, elicited by auditory stimuli. In these ten reports, the hearing loss accompanied by WE recovered relatively rapidly after thiamine repletion. Our case reports hearing loss occurring after WE and ongoing SNHL at oneyear follow-up after acute WE despite standard IV thiamine therapy and confirmation of serum thiamine repletion. Although the hearing impairment of our 28-year-old patient was classified by audiogram as mild sensorineural hearing loss, it was still significant enough for her to find that the bilateral hearing aid devices improved her quality of life.

Bariatric surgery increases the risk of thiamine deficiency, as thiamine absorption primarily occurs in the proximal small intestine. Thiamine is a coenzyme required by most cells for energy production in the form of adenosine triphosphate (ATP). When glucose is administered prior to thiamine repletion, ATP cannot be generated through the Krebs cycle, causing an increase in lactic acid production and eventual cell death [15]. In mice, an auditory neuropathy phenotype was created by deleting the high-affinity thiamine transporter encoded by SLC19A2, which is expressed in the inner hair cells within the cochlea. Cochlear histological analysis showed selective loss of inner hair cells one to two weeks after a low thiamine diet and significantly greater inner than outer hair cell loss after longer low-thiamine challenges (lasting three

Table 1. Cases of hearing loss and Wernicke encephalopathy

\begin{tabular}{|c|c|c|c|c|c|}
\hline Case & $\begin{array}{l}\text { Age } \\
\text { Sex }\end{array}$ & Risk factor for Bl deficiency & B1 level & SNHL after B1 repletion & Audiogram PTA \\
\hline Kondo, et al. [6] & $\begin{array}{c}28 \\
F\end{array}$ & $\begin{array}{l}\text { Gastric carcinoma, } \\
\text { chemotherapy }\end{array}$ & NR & $\begin{array}{l}\text { Resolved prior to } \\
\text { hospital discharge }\end{array}$ & NR \\
\hline Buscaglia, et al. [9] & $\begin{array}{l}17 \\
F\end{array}$ & Hyperemesis gravidarm & NR & $\begin{array}{l}\text { Improved prior to } \\
\text { hospital discharge }\end{array}$ & NR \\
\hline Foster, et al. [14] & $\begin{array}{c}35 \\
F\end{array}$ & Gastric bypass & NR & NR & NR \\
\hline Jethava, et al. [10] & $\begin{array}{c}44 \\
F\end{array}$ & Gastric bypass & $33 \mathrm{nmol} / \mathrm{L}$ & $\begin{array}{l}\text { Improved at } 8 \\
\text { week follow up }\end{array}$ & $\begin{array}{l}\text { Moderate } \\
\qquad(40 \mathrm{~dB} R, 50 \mathrm{~dB} L)\end{array}$ \\
\hline Zhang, et al. [11] & $\begin{array}{l}23 \\
M\end{array}$ & $\begin{array}{l}\text { Acute pancreatitis, } \\
1 \text { month limited diet }\end{array}$ & NR & $\begin{array}{l}\text { Improved } 2 \text { days } \\
\text { after treatment }\end{array}$ & NR \\
\hline Walker, et al. [3] & $\begin{array}{l}61 \\
M\end{array}$ & Diabetic gastroparesis & $35 \mathrm{nmol} / \mathrm{L}$ & $\begin{array}{l}\text { Resolved after } \\
24 \text { hours of treatment }\end{array}$ & $\begin{array}{l}\text { Moderate } \\
\qquad(40 \mathrm{~dB} R, 42 \mathrm{~dB} L)\end{array}$ \\
\hline Moussa, et al. [7] & $\begin{array}{l}49 \\
M\end{array}$ & $\begin{array}{l}\text { Emesis } 3 \text { months, } \\
\text { unknown cause }\end{array}$ & $36 \mathrm{nmol} / \mathrm{L}$ & $\begin{array}{l}\text { Resolved after } \\
2 \text { weeks }\end{array}$ & NR \\
\hline Nakamura, et al. [12] & $\begin{array}{l}61 \\
M\end{array}$ & $\begin{array}{l}\text { Alcoholism, gastric } \\
\text { resection for ulcer }\end{array}$ & $33 \mathrm{nmol} / \mathrm{L}$ & $\begin{array}{l}\text { Improved after } \\
3 \text { months }\end{array}$ & $\begin{array}{l}\text { Moderate ( } 40 \mathrm{~dB} \text { R, } 50 \mathrm{~dB} \mathrm{~L}) \\
\text { improved to mild ( } 23 \mathrm{~dB} \text { R, } \\
36 \mathrm{~dB} \mathrm{~L})\end{array}$ \\
\hline Nguyen, et al. [8] & $\begin{array}{c}35 \\
F\end{array}$ & Gastric sleeve & NR & $\begin{array}{l}\text { Resolved prior to } \\
\text { hospital discharge }\end{array}$ & NR \\
\hline Prosperini, et al. [13] & $\begin{array}{l}27 \\
M\end{array}$ & Gastric sleeve & NR & $\begin{array}{l}\text { Improved prior to } \\
\text { hospital discharge }\end{array}$ & Moderate (30 dB R, $50 \mathrm{~dB} L)$ \\
\hline
\end{tabular}

B1: Thiamine, SNHL: sensorineural hearing loss, PTA: pure tone average, NR: not reported 
weeks). When the mice on three-week low-thiamine challenge returned to a normal diet, slight improvements in average thresholds were noted after five weeks. However, the thresholds did not return to normal levels [15]. This mouse model suggests that hearing loss induced by thiamine deficiency may improve after the repletion of thiamine but it may not completely return to baseline. To help prevent thiamine deficiency, WE, and possibly irreversible hearing loss, it is vital that patients at risk of thiamine deficiency be repleted prior to initiation of infusions containing dextrose. It is important for providers to recognize non-alcoholic patients at high risk for thiamine deficiency, including those who have recently undergone bariatric surgery.

In the primary care setting, it is uncommon for young adults to endorse hearing loss. However, the number of patients undergoing bariatric surgery is growing. These patients are at an increased risk of vitamin deficiencies, along with their associated neurological and auditory complications, such as those occurring in WE. While some signs and symptoms resolve after immediate treatment, others, such as our patient's sensorineural hearing loss, can persist. Primary care and other providers caring for patients after bariatric surgery should refer symptomatic patients for audiological evaluations so that any hearing impairment can be diagnosed and treated to help improve patient care and quality of life.

\section{Acknowledgments}

None

\section{Conflicts of interest}

The authors have no financial conflicts of interest.

\section{Author Contributions}

Conceptualization: Angie Nu Ton. Data curation: Angie $\mathrm{Nu}$ Ton, Greta C Stamper. Formal analysis: Angie Nu Ton, Greta C Stamper. Investigation: Angie Nu Ton. Methodology: Angie Nu Ton. Project administration: Ashley Yenior. Resources: Trisha Jethwa. Software: Greta C Stamper. Supervision: Ashely Yenior. Validation: all authors. Visualization: Greta C Stamper. Writing - original draft: Angie Nu Ton. Writ-ing — review \& editing: all authors.

\section{ORCID iDs}

Angie $\mathrm{Nu}$ Ton

https://orcid.org/0000-0003-0063-6386
Trisha Jethwa Greta C Stamper Ashley Yenior https://orcid.org/0000-0003-1736-855X https://orcid.org/0000-0002-3741-5475 https://orcid.org/0000-0001-6282-867X

\section{REFERENCES}

1) Caine D, Halliday GM, Kril JJ, Harper CG. Operational criteria for the classification of chronic alcoholics: identification of Wernicke's encephalopathy. J Neurol Neurosurg Psychiatry 1997;62:51-60.

2) Antunez E, Estruch R, Cardenal C, Nicolas JM, Fernandez-Sola J, Urbano-Marquez A. Usefulness of CT and MR imaging in the diagnosis of acute Wernicke's encephalopathy. AJR Am J Roentgenol 1998;171:1131-7.

3) Walker MA, Zepeda R, Afari HA, Cohen AB. Hearing loss in Wernicke encephalopathy. Neurol Clin Pract 2014;4:511-5.

4) Singh S, Kumar A. Wernicke encephalopathy after obesity surgery: a systematic review. Neurology 2007;68:807-11.

5) Büki B, Jünger H, Zhang Y, Lundberg YW. The price of immune responses and the role of vitamin $d$ in the inner ear. Otol Neurotol 2019; 40:701-9.

6) Kondo K, Fujiwara M, Murase M, Kodera Y, Akiyama S, Ito K, et al. Severe acute metabolic acidosis and Wernicke's encephalopathy following chemotherapy with 5-fluorouracil and cisplatin: case report and review of the literature. Jpn J Clin Oncol 1996;26:234-6.

7) Moussa TD, Hamid A, Fatimata HD, Sofiane T. An unusual mode of revelation of Wernicke's encephalopathy: bilateral blindness with bilateral hypoacousia. Neurol India 2017;65:1406-7.

8) Nguyen JTT, Franconi C, Prentice A, Wycoco V. Wernicke encephalopathy hearing loss and palinacousis. Intern Med J 2019;49:536-9.

9) Buscaglia J, Faris J. Unsteady, unfocused, and unable to hear. Am J Med 2005;118:1215-7.

10) Jethava A, Dasanu CA. Acute Wernicke encephalopathy and sensorineural hearing loss complicating bariatric surgery. Conn Med 2012;76:603-5.

11) Zhang SQ, Guan YT. Acute bilateral deafness as the first symptom of Wernicke encephalopathy. AJNR Am J Neuroradiol 2012;33:E44-5.

12) Nakamura $T$, Imai $K$, Hamanaka $M$, Yamazaki $H$, Yamada $T$, Mizuno T. A case of Wernicke encephalopathy with hypoacusia and MR high intensity of the inferior colliculi that normalized after thiamine. Rinsho Shinkeigaku 2018;58:100-4.

13) Prosperini L, Stasolla A, Grieco G, Gerace C, Tortorella C. Non-alcoholic Wernicke encephalopathy presenting as bilateral hearing loss: a case report. J Neurol 2019;266:1027-30.

14) Foster D, Falah M, Kadom N, Mandler R. Wernicke encephalopathy after bariatric surgery: losing more than just weight. Neurology 2005; 65:1987; discussion 1847.

15) Liberman MC, Tartaglini E, Fleming JC, Neufeld EJ. Deletion of SLC19A2, the high affinity thiamine transporter, causes selective inner hair cell loss and an auditory neuropathy phenotype. J Assoc Res Otolaryngol 2006;7:211-7. 